Fixed Point Theory, 21(2020), No. 1, 375-388

DOI: $10.24193 /$ fpt-ro.2020.1.26

http://www.math.ubbcluj.ro/ nodeacj/sfptcj.html

\title{
A HYBRID PROJECTION ALGORITHM FOR FINDING FIXED POINTS OF BREGMAN QUASI-STRICT PSEUDO-CONTRACTIONS
}

\author{
ZI-MING WANG* AND SUN YOUNG CHO** \\ *Department of Foundation, Shandong Yingcai University, Jinan, China \\ ** Research Center for Interneural Computing, China Medical University Hospital, \\ China Medical University, Taichung, Taiwan \\ E-mail: ooly61@hotmail.com \\ Corresponding author
}

Abstract. In this paper, a hybrid projection algorithm is investigated for finding fixed points of Bregman quasi-strict pseudo-contractions. Strong convergence theorems are established in the framework of reflexive Banach spaces.

Key Words and Phrases: Bregman projection, monotone operator, Banach space, strong convergence, fixed point.

2010 Mathematics Subject Classification: 47H09, 65J15, 47H10.

\section{REFERENCES}

[1] G.A. Anastassiou, I.K. Argyros, Fixed point schemes with applications in right multivariate fractional calculus, J. Nonlinear Funct. Anal., 2016(2016), Art. ID 17.

[2] H.H. Bauschke, J.M. Borwein, P.L. Combettes, Essential smoothness, essential strict convexity, and Legendre functions in Banach spaces, Commun. Contemp. Math., 3(2001), 615-664.

[3] B.A. Bin Dehaish, A. Latif, H.O. Bakodah, X. Qin, A regularization projection algorithm for various problems with nonlinear mappings in Hilbert spaces, J. Inequal. Appl., 2015(2015), Art. ID 51 .

[4] B.A. Bin Dehaish, X. Qin, A. Latif, H.O. Bakodah, Weak and strong convergence of algorithms for the sum of two accretive operators with applications, J. Nonlinear Convex Anal., 16(2015), 1321-1336.

[5] J.F. Bonnans, A. Shapiro, Perturbation Analysis of Optimization Problems, Springer Verlag, New York, 2000.

[6] D. Butnariu, A.N. Iusem, Totally Convex Functions for Fixed Points Computation and Infinite Dimensional Optimization, Kluwer Academic Publ., Boston, Dordrecht, London, 2000.

[7] D. Butnariu, E. Resmerita, Bregman distances, totally convex functions and a method for solving operator equations in Banach spaces, Abstr. Appl. Anal., 2006(2006), Art. ID 84919.

[8] C. Byrne, A unified treatment of some iterative algorithms in signal processing and image reconstruction, Inverse Probl., 20(2008), 103-120.

[9] S.S. Chang, C.F. Wen, J.C. Yao, Common zero point for a finite family of inclusion problems of accretive mappings in Banach spaces, Optimization, 67(2018), 1183-1196. 
[10] S.S. Chang, C.F. Wen, J.C. Yao, Zero point problem of accretive operators in Banach spaces, Bull. Malaysian Math. Sci. Soc., 42(2019), 105-118.

[11] N. Fang, Y. Gong, Viscosity iterative methods for split variational inclusion problems and fixed point problems of a nonexpansive mapping, Commun. Optim. Theory, 2016(2016), Art. ID 11.

[12] H.O. Fattorini, Infinite-Dimensional Optimization and Control Theory, Cambridge University Press, Cambridge, 1999.

[13] F. Kohsaka, W. Takahashi, Proximal point algorithms with Bregman functions in Banach spaces, J. Nonlinear Convex Anal., 6(2005), 505-523.

[14] S.Y. Matsushita, W. Takahashi, A strong convergence theorem for relatively nonexpansive mappings in a Banach space, J. Approx. Theory, 134(2005), 257-266.

[15] X. Qin, A. Petruşel, J.C. Yao, CQ iterative algorithms for fixed points of nonexpansive mappings and split feasibility problems in Hilbert spaces, J. Nonlinear Convex Anal. 19(2018), 157-165.

[16] X. Qin, J.C. Yao, Projection splitting algorithms for nonself operators, J. Nonlinear Convex Anal. 18(2017), 925-935.

[17] X. Qin, J.C. Yao, Weak convergence of a Mann-like algorithm for nonexpansive and accretive operators, J. Inequal. Aappl., 2016(2016), Art. ID 232

[18] S. Reich, S. Sabach, A strong convergence theorem for a proximal-type algorithm in reflexive Banach spaces, J. Nonlinear Convex Anal., 10(2009), 471-485.

[19] S. Reich, S. Sabach, Two strong convergence theorems for a proximal method in reflexive Banach spaces, Numer. Funct. Anal. Optim., 31(2010), 22-44.

[20] S. Reich, S. Sabach, Two strong convergence theorems for Bregman strongly nonexpansive operators in reflexive Banach spaces, Nonlinear Anal., 73(2010), 122-135.

[21] R.T. Rockafellar, Characterization of the subdifferentials of convex functions, Pacific J. Math., 17(1966), 497-510.

[22] G.C. Ugwunnadi et al., Strong convergence theorem for quasi-Bregman strictly pseudocontractive mappings and equilibrium problems in Banach spaces, Fixed Point Theory Appl., 2014(2014), Art. ID 231.

[23] Z.M. Wang, X. Zhang, Shrinking projection methods for systems of mixed variational inequalities of Browder type, systems of mixed equilibrium problems and fixed point problems, J. Nonlinear Funct. Anal., 2014(2014), Art. ID 15.

[24] C. Zălinescu, Convex Analysis in General Vector Spaces, World Scientific, River Edge, 2002.

Received: September 30, 2016; Accepted: March 20, $201 \%$. 